UDC 316.334 .52

LBC 60.59

\title{
SOCIO-CULTURAL POTENTIAL OF RURAL REGIONS OF BELARUS IN THE CONTEXT OF CULTURAL SERVICES CONSUMPTION: SOCIOLOGICAL ANALYSIS
}

\author{
Natalia L. Balich \\ Institute of Sociology of the National Academy of Sciences of Belarus, Minsk, Republic of Belarus
}

\begin{abstract}
The author considers socio-cultural potential of rural regions in the context of the cultural services consumption by the rural population. The researcher carries out the analysis of social and cultural infrastructure development of the village, gives numerical indicators of the activities of concert organizations, libraries, club institutions and formations, paid services in dynamics for 2010-2016. The paper reveals the degree of satisfaction of various social and age groups of the rural population with the quality of educational and cultural services at the place of residence, the availability of opportunities to visit cultural and leisure activities and cultural institutions. The given survey is based on the data of empirical research conducted by the Institute of Sociology of the National Academy of Sciences of Belarus in 2018. The author compares subjective assessments of their material well-being of groups with different social status with the average income per family member, the minimum subsistence budget in the context of opportunities to pay for educational paid clubs for their children, pre-school institutions. The researcher concludes that the most economically vulnerable group not having sufficient funds to pay for cultural services and activities are peasants, agricultural workers. Self-assessments of the modest financial situation and requests for cultural and leisure services correlate with the low level of income of this social group. The conducted study determines that the socio-cultural potential of rural regions largely depends on the specifics of the socio-cultural infrastructure of the modern village, the totality of social, cultural and economic resources. In contrast to the city, the socio-cultural infrastructure of rural regions is less developed and equipped with material and technical means. The author highlights that in successful realization of socio-cultural potential of different groups of rural population, a major role is played by the services of the population in the field of culture, which should be accessible regardless of social status and place of residence. The researcher underlines that it is necessary to create comfortable living conditions in rural areas, to provide local residents with not only material but also spiritual well-being. Ignoring the existing problems of the development of socio-cultural infrastructure and culture in rural areas will lead to a further outflow of young people and skilled working-age population to the city.

Key words: socio-cultural potential, consumption, cultural services, rural regions, rural population.
\end{abstract}

УДК 316.334 .52

ББК 60.59

\section{СОЦИАЛЬНО-КУЛЬТУРНЫЙ ПОТЕНЦИАЛ СЕЛЬСКИХ РЕГИОНОВ БЕЛАРУСИ В КОНТЕКСТЕ ПОТРЕБЛЕНИЯ КУЛЬТУРНЫХ УСЛУГ: СОЦИОЛОГИЧЕСКИЙ АНАЛИЗ}

\author{
Наталья Леонидовна Балич \\ Институт социологии НАН Беларуси, г. Минск, Республика Беларусь
}

Аннотация. В статье рассматривается социально-культурный потенциал сельских регионов в контексте потребления культурных услуг сельским населением. Проводится анализ развитости социальнокультурной инфраструктуры села, приводятся численные показатели деятельности концертных организаций, библиотек, клубных учреждений и формирований, а также платные услуги в динамике за 2010- 
2016 годы. На основе данных эмпирического исследования, проведенного Институтом социологии НАН Беларуси в 2018 г., выявляется удовлетворенность различных социальных и возрастных групп сельского населения качеством образовательных, культурных услуг по месту жительства, наличием возможностей для посещения культурно-досуговых мероприятий и учреждений культуры. Субъективные оценки материального достатка групп с различным социальным положением сопоставляются со средним доходом на члена семьи, бюджетом прожиточного минимума в контексте возможностей оплачивать развивающие платные кружки для своих детей, дошкольные учреждения. Сделан вывод о том, что экономически наиболее уязвимой группой, не имеющей достаточных средств для оплаты культурных услуг и мероприятий, являются крестьяне, работники сельского хозяйства. Самооценки скромного финансового положения и запросов на культурно-досуговые услуги коррелируют с низким уровнем дохода данной социальной группы. Определено, что социально-культурный потенциал сельских регионов во многом зависит от специфики социально-культурной инфраструктуры современного села, совокупности социальных, культурных, экономических ресурсов. В отличие от города социально-культурная инфраструктура сельских регионов характеризуется меньшей развитостью и оснащенностью материально-техническими средствами. В успешной реализации социально-культурного потенциала разных групп сельского населения большую роль играют услуги населению в сфере культуры, которые должны быть доступными независимо от социального положения и места жительства. Необходимо создавать комфортные условия проживания в сельской местности, обеспечивать местным жителям не только материальное, но и духовное благополучие. Игнорирование существующих проблем развития социально-культурной инфраструктуры и культуры на селе приведет к дальнейшему оттоку молодежи и квалифицированного трудоспособного населения в города.

Ключевые слова: социально-культурный потенциал, потребление, культурные услуги, сельские регионы, сельское население.

Социально-культурный потенциал территории - важнейший фактор социально-экономического и культурного развития регионов. Актуальность исследования социально-культурного потенциала заключается в том, что от его эффективной реализации в социальной, экономической, культурной сферах зависит развитие сельских территорий, интеллектуальное и духовно-нравственное развитие села, сохранение и преумножение его культурного наследия. Данные положения развернуто представлены в «Программе социально-экономического развития Республики Беларусь на 2016-2020 годы», а также в Национальной стратегии устойчивого социально-экономического развития Республики Беларусь до 2020 года. В частности, в Программе в целях реализации социально-культурного потенциала предусматривается «создание современных центров культуры и услуг, в том числе путем реорганизации районных и сельских учреждений культуры, развития нестационарных форм обслуживания жителей малонаселенных пунктов, создания организаций культуры смешанного типа, иных многофункциональных учреждений культуры, с максимальным использованием регионального творческого потенциала» [Программа... web, 72].
Реализация социально-культурного потенциала региона во многом зависит от совокупности человеческих, социальных, культурных, трудовых, материально-технических ресурсов, обечивающих качество жизни на селе в контексте развития экономики и культуры региона. Социально-культурные учреждения (музеи, библиотеки, клубы, центры ремесел, художественные, музыкальные школы и др.) удовлетворяют растущие культурные и эстетические потребности населения, создают условия для культурного досуга и отдыха, повышают общеобразовательный и культурный уровень сельской молодежи.

Проблематика формирования и реализации социально-культурного потенциала не в полной мере раскрыта в научных трудах, посвященных вопросам регионального развития.

Большинство публикаций посвящены различным аспектам реализации экономического потенциала в контексте социально-экономического развития регионов [Никулина, Чистникова, Орлова 2012], конкурентоспособности экономического кластера как формы успешной хозяйственной деятельности регионов [Сахарова web]. Специфика управления конкурентоспособностью регионов содержательно представлена зарубежными исследовате- 
лями. В частности, М.Е. Портер движущей силой их развития считал эффективное использование имеющихся ресурсов, способных повысить конкурентоспособность конкретного региона и его оценку [Porter web].

Природно-ресурсный потенциал регионов и возможности их эффективного освоения с экономической эффективностью анализируется российскими [Лемдяева web] и белорусскими учеными [Сидорова 2012]. Финансовому потенциалу отводится роль главного составляющего общего потенциала регионов [Васильева, Яковлева, Николаева web], финансово-инвестиционный потенциал представлен как фактор устойчивого развития региона [Зайцев, Худяков 2013], в том числе при исследовании определенной области [Сахарова web], агропромышленного комплекса [Терентьева, Баскаков 2014]. Нередко исследователи различных видов потенциала не учитывают специфику сельских регионов, забывая, что каждая территория имеет свои уникальные социокультурные характеристики и потенциал. По справедливому утверждению Р.А. Смирновой, «социокультурные характеристики сельского сообщества до сих пор должным образом не поняты и не оценены, что снижает потенциал социально-экономической политики реформ АПК и других программ, направленных на развитие как села, так и всего белорусского общества» [Смирнова 2012, 290-291].

Социально-экономическое и культурное развитие сельских регионов даже в границах одного государства сложно измерить по одной универсальной модели. Для объективного анализа имеющихся проблем важно проводить опросы общественного мнения сельских жителей с выделением специфики конкретных территорий.

Термин «потенциал» (от лат. potentia «могущий», «могущий быть») в контексте исследования социально-культурного потенциала сельских регионов подразумевает совокупность социальных, культурных, экономических ресурсов, которые используются для социально-культурного развития сельских регионов. В «Программе социально-экономического развития Республики Беларусь на 2016-2020 годы» одной из задач социальной политики Белорусского государства являет- ся «направленность на обеспечение достойного уровня и качества жизни белорусских граждан, укрепление демографического потенциала» [Программа... web]. Соответственно, учреждения культуры призваны приобщать людей к достижениям культуры, воспитывать культурного человека независимо от места его проживания.

Сельским регионам сложно конкурировать с городом по количеству социально-культурных и образовательных учреждений, разнообразию бесплатных и платных образовательно-культурных услуг. Меньшая развитость учреждений культуры (кинотеатров, библиотек, клубов, музеев, театров) на селе либо их отсутствие ограничивает возможности сельчан пользоваться культурными услугами - посещать концерты, спектакли, музеи, смотреть новинки кинопроката в хорошем качестве, получать информационно-библиотечные услуги и т. д. Местный дом культуры нередко является единственным объектом досуга и центром культурной жизни в сельской местности, ориентированным на проведение разноплановых мероприятий.

Ограниченные возможности вытекают из специфики социально-культурной инфраструктуры села, которая меньше обеспечена объектами социальной, культурной, производственной сферы, хуже оснащена современными техническими средствами по сравнению с городом. Среди причин небольшого объема оказываемых услуг сельскому населению белорусский исследователь Н.Е. Лихачёв отмечает экономические проблемы местных субъектов хозяйствования, ограниченность выделяемых средств из госбюджета, что не позволяет в полной мере «обеспечить социокультурные и бытовые запросы сельчан в широком ассортименте. Сельские жители оказались в неравных условиях по сравнению с горожанами по уровню комфортности жилья, состоянию дорог, духовному развитию» [Cоколова, Кобяк (сост.) 2013, 428].

Гастрольные концерты становятся ярким событием для местных жителей. Показатели деятельности концертных организаций в сельских населенных пунктах и агрогородках косвенно свидетельствуют о финансовой рентабельности и социальной востребованности данных мероприятий. Динамика гастрольных 
концертов, проведенных для жителей села и агрогородков за 2010-2016 гг,, отражает существенное снижение количества данных мероприятий (более чем в два раза), что, несомненно, снижает уровень обеспечения культурного досуга сельских жителей (рис. 1).

Среди базовых элементов культурной инфраструктуры сокращается численность районных исторических, краеведческих музеев, клубных учреждений, библиотек, что снижает возможности интеллектуально-культурного досуга сельских жителей. Согласно данным Национального статистического комитета Республики Беларусь такая тенденция характерна не только для сельских регионов, но и для городов, поселков городского типа (рис. 2). Несмотря на то что численность сельских библиотек больше, чем городских, количество пользователей на одну библиотеку в городах в 8-9 раз превышает их количество в сельской местности.

\section{Количество концертов, проведенных для жителей сельских населенных пунктов и агрогородков (2010-2016 гг.)}

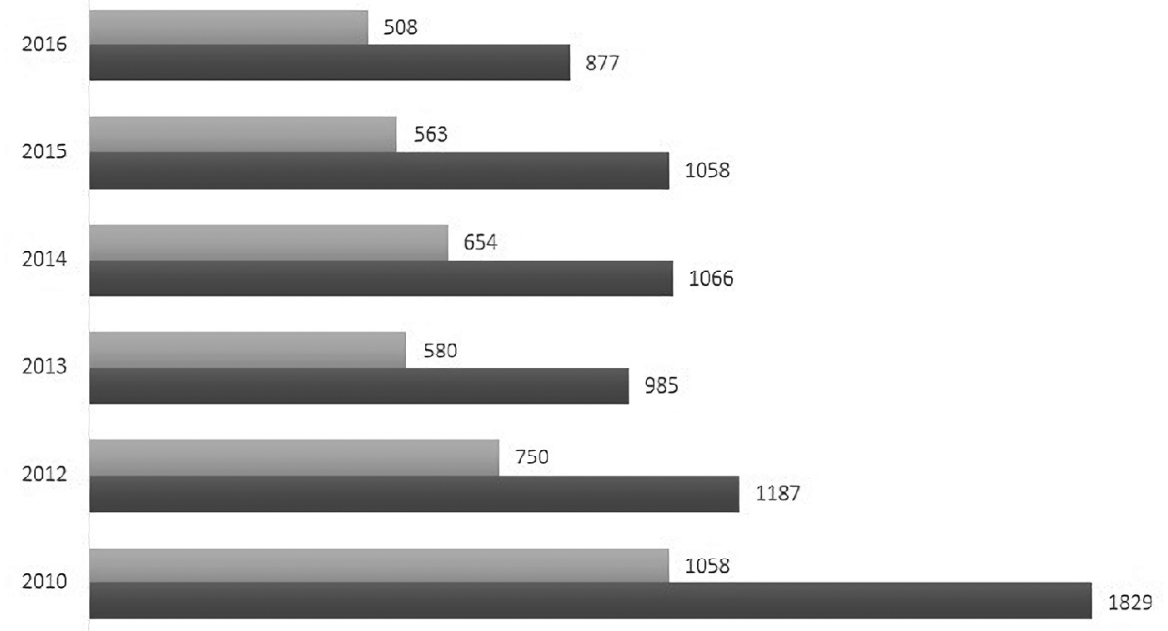

Концерты для жителей агрогородков

Рис. 1. Показатели деятельности концертных организаций (2010-2016 гг.) Примечание. Составлено по: [Медведева (ред.) 2017, 37].

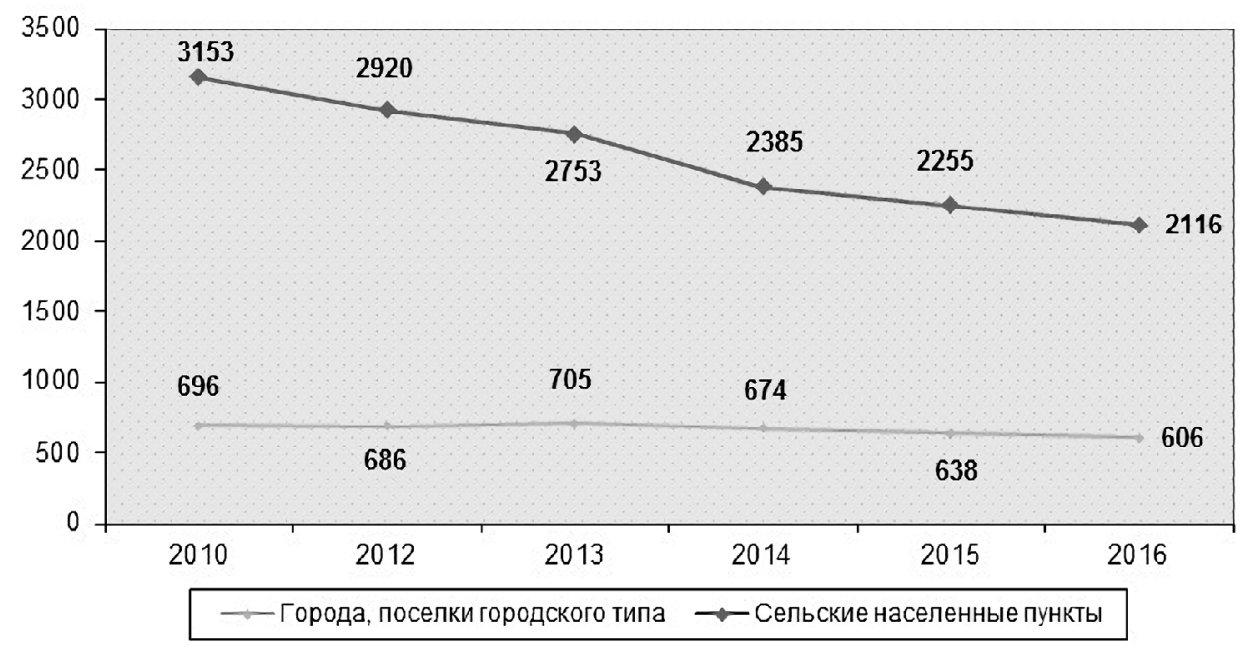

Рис. 2. Динамика численности библиотек в городах и селах Беларуси (2010-2016 гг.) Примечание. Составлено по: [Медведева (ред.) 2017, 42]. 


\section{БЕЛОРУССКАЯ АКАДЕМИЧЕСКАЯ СОЦИОЛОГИЯ}

Согласно данным, представленным на рисунке 3 , количество пользователей как в городских, так и в сельских библиотеках в период 2010-2016 г. не снизилось, что говорит о востребованности данных учреждений. На конец 2016 г. средняя численность городских читателей на одну библиотеку составила 3724 чел., на одну библиотеку среди жителей села -420 человек (рис. 3).

Для выявления у сельского населения уровня удовлетворенности работой учреждений социально-культурной сферы, а также востребованности услуг данных учреждений на селе было проведено социологическое исследование социально-культурного потенциала сельских регионов Беларуси (государственное задание 3.1 .04 «Социодинамика социальной структуры сельских регионов» на 20162020 гг.).

С этой целью в рамках мониторинга социально-политической, экономической и социокультурной ситуации в Республике Беларусь Институтом социологии НАН Беларуси в июне 2018 г. был проведен республиканский опрос (случайная республиканская многоступенчатая выборка с контролем квот на последнем этапе по признакам пола, возраста, образования, $\mathrm{N}=2100$, в том числе сельское население - 556 чел.). При построении модели выборки учитывалось административнотерриториальное деление Республики, зональ- ная принадлежность населенного пункта, демографическая структура выделяемых зон. Сельские населенные пункты входят в определенную зону в зависимости от типа районного центра, которому подчинены. В выборочную совокупность попадают все области Республики с учетом численности населения.

Среди трудоспособного населения, проживающего на селе, в выборке больше всего представлено рабочих (промышленности, транспорта, строительства) - 11,2\%; крестьян, работников сельского хозяйства $-10,7 \%$. Существенную долю в структуре сельского населения составляют неработающие пенсионеры - 29,2 \%.

Оценки сельским населением качества социально-культурных услуг свидетельствуют, что образовательными услугами, предоставляемыми по месту жительства, сельские жители удовлетворены больше, чем услугами организаций отдыха и досуга, работой кинотеатров, библиотек, музеев, театров (см. табл. 1).

Среди сельского населения, проживающего в разных областях Беларуси, наиболее высокий уровень удовлетворенности наличием и работой различных объектов культуры выразили жители Гомельской области $(59,1 \%)$, низкий - жители Витебской области $(21,7 \%)$. В данной группе представлено больше всего лиц, затруднившихся ответить на вопрос об

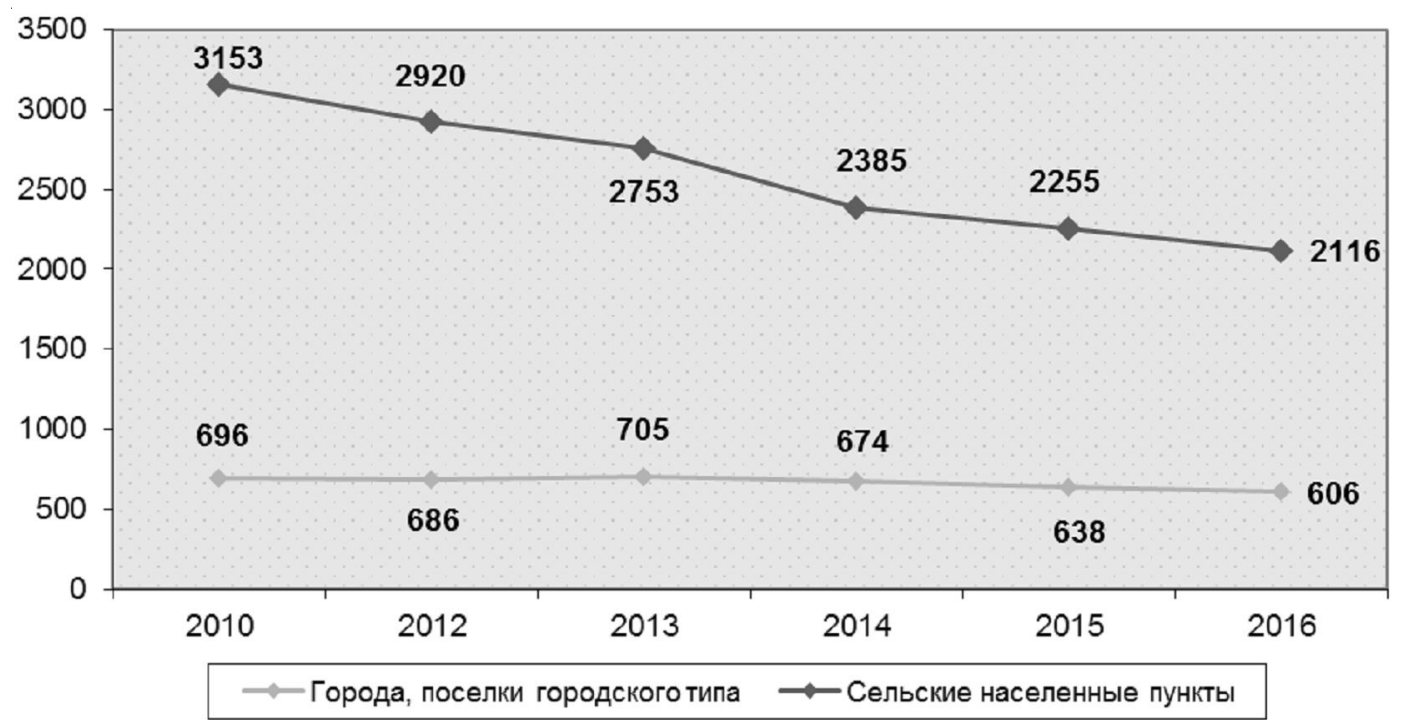

Рис. 3. Динамика численности пользователей в среднем на одну библиотеку в городских и сельских населенных пунктах Беларуси (2010-2016 гг.)

Примечание. Составлено по: [Медведева (ред.) 2017, 42]. 
удовлетворенности работой объектов культуры (47,7\%). Следует отметить также мнение населения Могилевской области, среди которых 42,8 \% респондентов не удовлетворены работой местных кинотеатров, библиотек, музеев и других объектов культуры.

Качество услуг в сфере образования наиболее высоко оценили жители Гродненской $(76,0 \%)$ и Брестской $(70,0 \%)$ областей, низкий уровень удовлетворенности (40,0 \%) зафиксирован среди жителей Витебской области.

Работой организаций, отвечающих за досуг и отдых населения, больше всего удовлетворены жители Гомельской области $(54,3 \%)$, меньше всего - Витебской $(18,0 \%)$ и Могилевской $(24,1 \%)$ областей.

В сравнительных оценках качества и доступности различных образовательных, досуговых услуг на селе, качеством работы кинотеатров, библиотек, музеев, театров выделяются сельские жители Могилевской и Витебской областей. Так, среди могилевчан больше всего тех, кто не удовлетворен качеством оказываемых услуг по месту жительства, а среди витебчан - тех, кто затруднился выразить свое мнение (табл. 2).

В различных возрастных группах старшее поколение (от 50 лет) позитивнее, в отличие от молодежи, воспринимает качество оказываемых услуг организациями досуга и отдыха, объектами культуры по месту жительства и более критично к современным образовательным услугам. Младшая (до 30 лет) и средняя (30-49 лет) возрастные группы, напротив, больше довольны качеством услуг образования по месту жительства и менее удовлетворены организацией досуга и отдыха, работой кинотеатров, библиотек, музеев, театров (см. табл. 3).

В процессе исследования было обращено внимание на оценку респондентами своих финансовых возможностей для посещения культурно-досуговых мероприятий и учреждений культуры. При сравнении ответов участников опроса с различным социальным положением были получены следующие результаты. Больше всего респондентов, считающих, что у них достаточно денег для посещения

Таблища 1

\section{Удовлетворенность сельского населения качеством услуг по месту жительства (2018 г.), \%}

\begin{tabular}{|l|c|c|c|c|}
\hline \multicolumn{1}{|c|}{ Вид услуг } & Нет ответа & Удовлетворены & Не удовлетворены & $\begin{array}{c}\text { Затруднились } \\
\text { ответить }\end{array}$ \\
\hline Услуги образования & 0,4 & 58,7 & 20,6 & 20,3 \\
\hline Организации досуга и отдыха & 1,1 & 40,4 & 33,8 & 24,7 \\
\hline $\begin{array}{l}\text { Объекты культуры (кинотеатры, } \\
\text { библиотеки, музеи, театры и т. д.) }\end{array}$ & 0,5 & 45,6 & 28,2 & 25,6 \\
\hline
\end{tabular}

Таблица 2

Удовлетворенность сельского населения различных областей Беларуси качеством услуг по месту жительства (2018 г.), \%

\begin{tabular}{|c|c|c|c|c|c|c|}
\hline Оценка & $\begin{array}{c}\text { Брестская } \\
\text { область } \\
\end{array}$ & $\begin{array}{c}\text { Гродненская } \\
\text { область } \\
\end{array}$ & $\begin{array}{c}\text { Гомельская } \\
\text { область }\end{array}$ & $\begin{array}{c}\text { Могилевская } \\
\text { область }\end{array}$ & $\begin{array}{c}\text { Минская } \\
\text { область }\end{array}$ & $\begin{array}{c}\text { Витебская } \\
\text { область }\end{array}$ \\
\hline \multicolumn{7}{|c|}{ Услуги образования } \\
\hline Нет ответа & 0,6 & - & 1,9 & - & - & - \\
\hline Удовлетворены & 70,0 & 76,0 & 59,9 & 46,2 & 55,8 & 40,0 \\
\hline Не удовлетворены & 7,3 & 9,6 & 16,0 & 34,9 & 31,6 & 23,0 \\
\hline Затруднились ответить & 22,1 & 14,4 & 22,2 & 18,9 & 12,6 & 37,0 \\
\hline \multicolumn{7}{|c|}{ Организаичи досуга и отдыхха } \\
\hline Нет ответа & 0,6 & - & 4,3 & 2,5 & - & - \\
\hline Удовлетворены & 43,8 & 47,6 & 54,3 & 24,1 & 44,7 & 18,0 \\
\hline Не удовлетворены & 22,5 & 35,0 & 14,2 & 60,9 & 41,5 & 34,6 \\
\hline Затруднились ответить & 33,1 & 17,4 & 27,2 & 12,5 & 13,8 & 47,4 \\
\hline \multicolumn{7}{|c|}{ Объектыл культуры (кинотеатры, библиотеки, музеи, театры и т. д.) } \\
\hline Нет ответа & 0,6 & - & 1,9 & - & 0,5 & - \\
\hline Удовлетворены & 47,1 & 49,6 & 59,1 & 35,6 & 51,3 & 21,7 \\
\hline Не удовлетворены & 18,6 & 33,2 & 12,0 & 42,8 & 35,0 & 30,6 \\
\hline Затруднились ответить & 33,7 & 17,2 & 27,0 & 21,6 & 13,2 & 47,7 \\
\hline
\end{tabular}




\section{БЕЛОРУССКАЯ АКАДЕМИЧЕСКАЯ СОЦИОЛОГИЯ}

концертов, театров, кино, музеев, зафиксировано среди предпринимателей, фермеров $(53,5 \%)$, а также учащихся и студентов $(40,4 \%)$. На недостаточность финансовых средств больше всего указали служащие без специального образования (секретари, регистраторы и т. п.) - 42,8 \% и безработные-32,6 \%.

Возможности для посещения культурнодосуговых мероприятий есть не у всех, о чем свидетельствуют данные опроса. Доля респондентов, отметивших отсутствие средств для оплаты культурно-досуговых мероприятий («денег никогда не хватит»), выше в группе крестьян, работников сельского хозяйства $(12,1 \%)$, рабочих сферы промышленности, транспорта, строительства (10,9\%), учащихся, студентов (10,7\%).

Есть среди опрошенных и те, кто не заинтересован либо не считает нужным по различных причинам покупать билеты на подобные мероприятия. Это руководители высшего, среднего, низшего звена (64,1 \%), крестьяне, работники сельского хозяйства $(53,8 \%)$ (рис. 4).

\section{Удовлетворенность различных возрастных групп}

сельского населения качеством услуг по месту жительства (2018 г.), \%

\begin{tabular}{|l|c|c|c|}
\hline \multirow{2}{*}{ Оценка } & \multicolumn{3}{|c|}{ Возраст, лет } \\
\cline { 2 - 4 } & $16-29$ & $30-49$ & 50 и старше \\
\hline \multicolumn{4}{|c|}{ Услуги образования } \\
\hline Нет ответа & - & - & 0,8 \\
\hline Удовлетворены & 63,0 & 65,2 & 52,5 \\
\hline Не удовлетворены & 21,1 & 21,2 & 20,0 \\
\hline Затруднились ответить & 16,0 & 13,5 & 26,6 \\
\hline \multicolumn{4}{|c|}{ Организаичии досуга и отдыха } \\
\hline Нет ответа & - & 1,2 & 1,4 \\
\hline Удовлетворены & 38,3 & 36,5 & 43,9 \\
\hline Не удовлетворены & 42,3 & 44,2 & 23,5 \\
\hline Затруднились ответить & 19,4 & 18,2 & 31,2 \\
\hline \multicolumn{1}{|c|}{ Объекты культуры (кинотеатрыл, библиотеки, музеи, театры и т. д.) } \\
\hline Нет ответа & 0,7 & - & 0,8 \\
\hline Удовлетворены & 43,3 & 44,8 & 47,1 \\
\hline Не удовлетворены & 36,4 & 35,2 & 20,2 \\
\hline Затруднились ответить & 19,6 & 20,0 & 31,9 \\
\hline
\end{tabular}

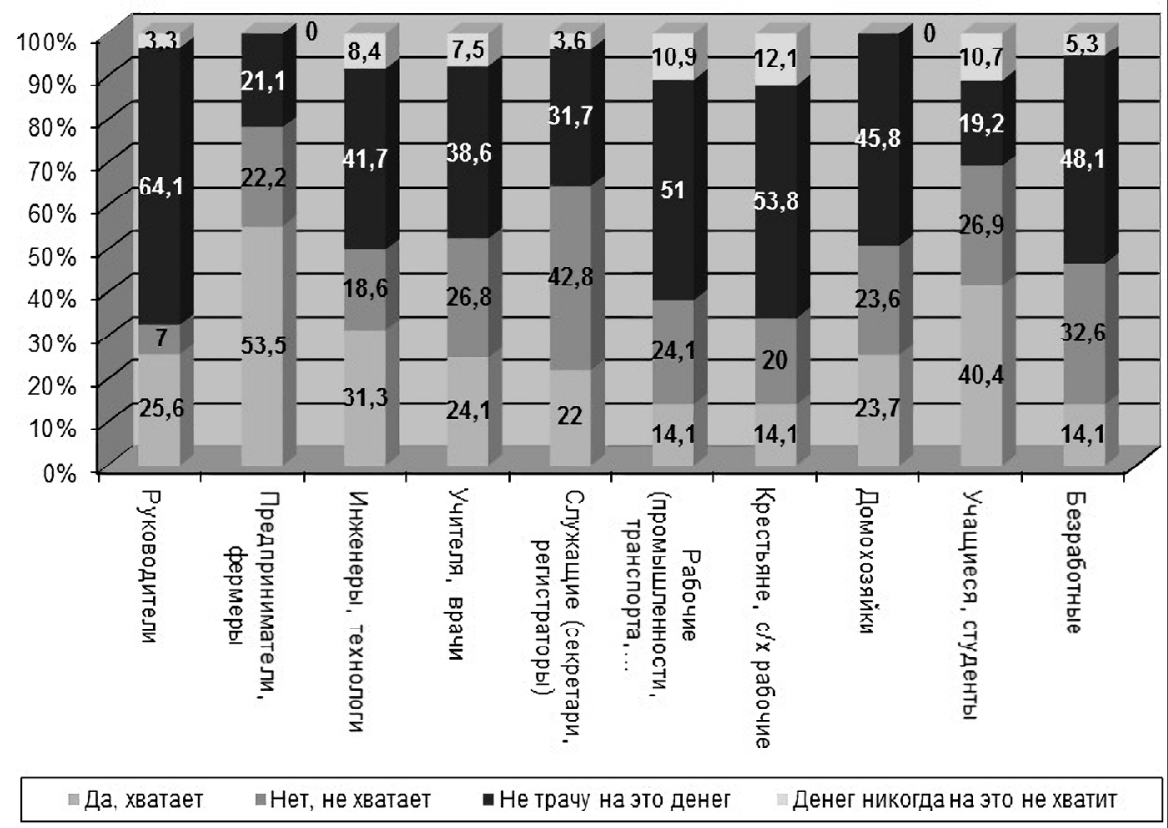

Рис. 4. Наличие у сельского населения с различным социальным положением средств для оплаты билетов на концерты, выставки, в театры и кино (2018 г.), \% 
Большую роль в организации культурного досуга сельчан играет культурно-просветительская работа клубных учреждений. В них проводятся концерты и спектакли любительских коллективов народного творчества, выставки произведений народного творчества и декоративно-прикладного искусства. Культурно-просветительская работа сельских клубных учреждений характеризуется возрастающей коммерциализацией. В динамике 2010-2016 гг. ежегодно растет количество платных концертов и спектаклей, театрализованных праздников, выставок, что ограничивает возможности малообеспеченных и социально уязвимых групп сельского населения культурно и организованно проводить свой досуг (табл. 4).

Основные показатели деятельности клубных учреждений в динамике за 20102016 гг. свидетельствуют о сокращении чис- ленности клубов на 859 единиц по Республике и, соответственно, количества посадочных мест (табл. 5).

В период с 2010 по 2016 г. существенно сократилось количество клубных формирований (на 4000 единиц), в числе которых любительские коллективы художественного творчества, студии, кружки. Соответственно, сократилась численность участников клубных объединений по различным интересам, согласно данным официальной статистики - на 53000 чел. на конец 2016 года (табл. 6).

Среди причин закрытия сельских клубов и домов культуры современные исследователи называют отсутствие финансовых средств для их полноценной работы. Поэтому «не развивается сеть музыкальных, спортивных школ, секций любительского творчества для детей. В сельской местности низка обеспеченность кадрами врачей и учителей, сокращается чис-

Культурно-просветительская работа

Таблииа 4 сельских клубных учреждений (2010-2016 гг.), тыс. ед.

\begin{tabular}{|l|c|c|c|c|c|c|}
\hline \multicolumn{1}{|c|}{ Показатели работы } & 2010 & 2012 & 2013 & 2014 & 2015 & 2016 \\
\hline $\begin{array}{l}\text { Число концертов, спектаклей, любительских } \\
\text { коллективов народного творчества }\end{array}$ & 75,4 & 83,0 & 94,5 & 84,6 & 85,9 & 88,9 \\
\hline из них на платной основе & 7,4 & 7,6 & 9,7 & 9,2 & 9,9 & 11,7 \\
\hline $\begin{array}{l}\text { Число театрализованных праздников, обрядов, } \\
\text { представлений }\end{array}$ & 28,9 & 31,6 & 37,1 & 33,7 & 35,3 & 36,3 \\
\hline из них на платной основе & 3,4 & 4,0 & 4,4 & 4,4 & 4,8 & 5,1 \\
\hline $\begin{array}{l}\text { Число выставок произведений народного твор- } \\
\text { чества и декоративно-прикладного искусства }\end{array}$ & 25,8 & 29,7 & 31,7 & 32,1 & 33,1 & 34,9 \\
\hline из них на платной основе & 0,5 & 0,7 & 0,9 & 0,9 & 0,9 & 1,0 \\
\hline
\end{tabular}

Примечание. Составлено по: [Медведева (ред.) 2017,90].

Таблииа 5

Численность сельских клубных учреждений на конец года (2010-2016 гг.)

\begin{tabular}{|l|c|c|c|c|c|c|}
\hline \multicolumn{1}{|c|}{ Показатели деятельности } & 2010 & 2012 & 2013 & 2014 & 2015 & 2016 \\
\hline Число клубных учреждений & 3124 & 2904 & 2742 & 2486 & 2382 & 2265 \\
\hline B них посадочных мест, mblc. ед. & 551,6 & 510,2 & 483,5 & 438,4 & 417,3 & 394,0 \\
\hline
\end{tabular}

Примечание. Составлено по: [Медведева (ред.) 2017, 89].

Таблица 6

Динамика численности клубных формирований и их участников на селе (на конец года)

\begin{tabular}{|c|c|c|c|c|c|c|}
\hline \multicolumn{1}{|c|}{ Показатели деятельности } & 2010 & 2012 & 2013 & 2014 & 2015 & 2016 \\
\hline Число клубных формирований, тыс. ед. & 20,0 & 19,3 & 18,8 & 17,1 & 16,8 & 16,0 \\
\hline $\begin{array}{l}\text { в том числе студий, любительских коллекти- } \\
\text { вов художественного творчества }\end{array}$ & 14,8 & 13,9 & 13,4 & 11,9 & 11,9 & 10,6 \\
\hline $\begin{array}{l}\text { Численность участников клубных формирова- } \\
\text { ний, тыс. чел. }\end{array}$ & 193,3 & 182,2 & 175,2 & 154,5 & 150,6 & 140,4 \\
\hline $\begin{array}{l}\text { в том числе участников студий, любительских } \\
\text { коллективов художественного творчества }\end{array}$ & 132,0 & 121,4 & 115,1 & 99,6 & 94,4 & 86,8 \\
\hline
\end{tabular}

Примечание. Составлено по: [Медведева (ред.) 2017, 89]. 


\section{БЕЛОРУССКАЯ АКАДЕМИЧЕСКАЯ СОЦИОЛОГИЯ}

ло дошкольных учреждений» [Соколова, Кобяк (сост.) 2013, 429].

Количество платных мероприятий в клубных учреждениях на конец 2016 г. также существенно снизилось. Почти в 2,5 раза уменышилось число посетителей платных мероприятий (табл. 7).

Финансовые возможности родителей во многом определяют организацию культурного досуга их детей.

Государство обеспечивает доступность посещения дошкольных учреждений всем детям.

Родители в обязательном порядке оплачивают питание детей. Пребывание же ребен- ка в саду, включая уход, присмотр, воспитание, обучение, остается бесплатным. Исключение составляют платные кружки, посещение которых детьми возможно по желанию родителей. Возможности есть не у всех, о чем свидетельствуют данные опроса. Доля таких респондентов выше в группе служащих производственной сферы (инженеров, технологов) $-8,4 \%$, которые считают, что для этого у них «никогда не хватит денег», и учителей, врачей $-5,6 \%$. Респондентов, указавших на недостаточное количество средств для оплаты кружков и дошкольных учреждений, больше всего в группе фермеров, предпринимателей $-22,1 \%$ (рис. 5).

Таблица 7

Динамика платных мероприятий клубных учреждений и численности посетителей на конец года (2010-2016 гг.)

\begin{tabular}{|l|c|c|c|c|c|c|}
\hline \multicolumn{1}{|c|}{ Показатели деятельности } & 2010 & 2012 & 2013 & 2014 & 2015 & 2016 \\
\hline $\begin{array}{l}\text { Число мероприятий на платной } \\
\text { основе, тыс. ед. }\end{array}$ & 244,3 & 217,3 & 195,7 & 168,2 & 151,3 & 140,8 \\
\hline $\begin{array}{l}\text { Численность посетителей плат- } \\
\text { ных мероприятий, млн чел. }\end{array}$ & 7,1 & 5,2 & 4,5 & 3,7 & 3,2 & 2,9 \\
\hline
\end{tabular}

Примечание. Составлено по: [Медведева (ред.) 2017, 89].

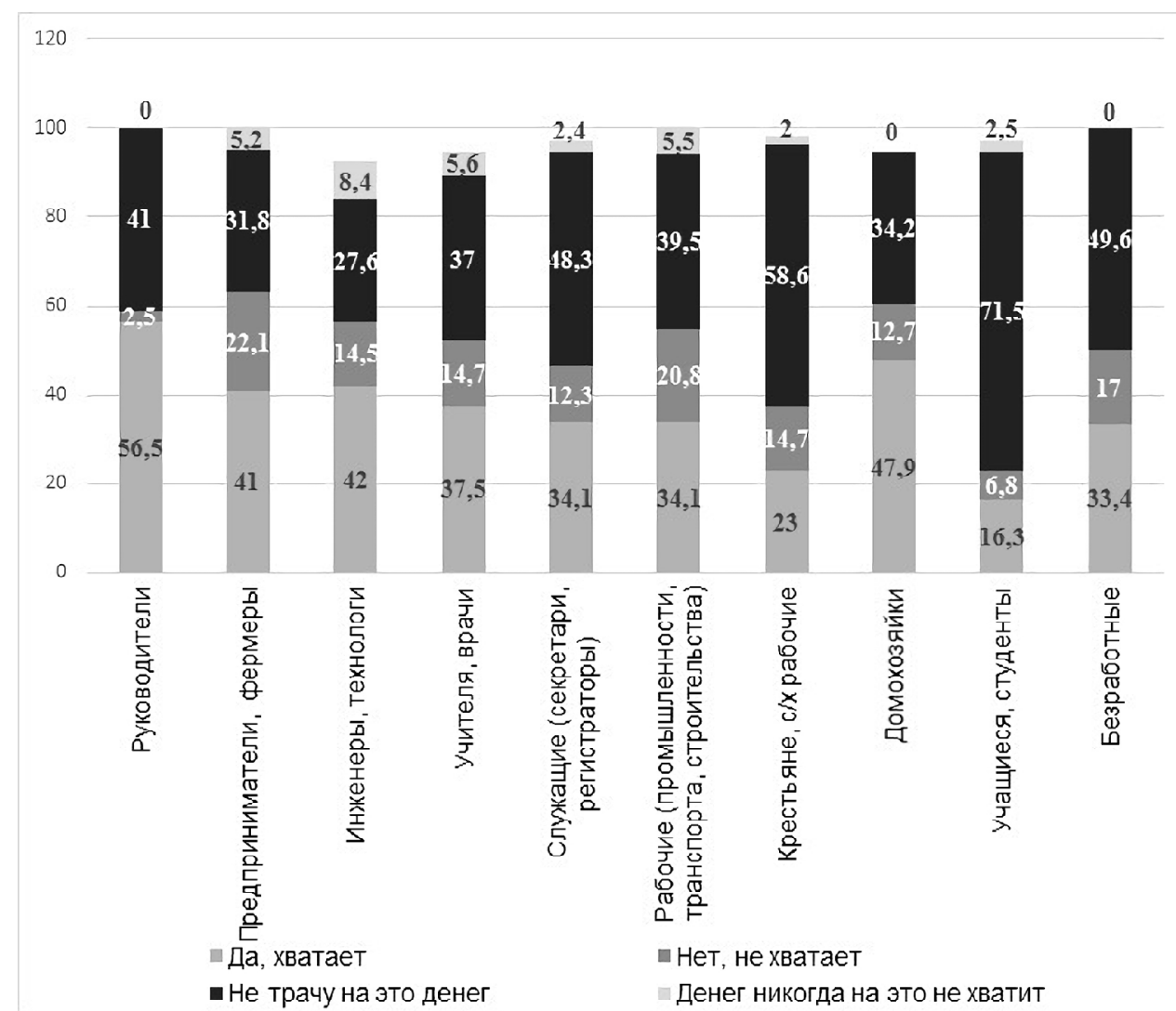

Рис. 5. Наличие у сельского населения с различным социальным положением финансовых возможностей для оплаты детских дошкольных учреждений, кружков (2018 г.), \% 
В процессе исследования выявлена субъективная оценка респондентами материального положения своей семьи. Среди групп с различным социальным положением большинство (кроме крестьян, работников сельского хозяйства) оценивают свое материальное положение как среднее. Выше доля тех, кто определяет материальное положение своей семьи как хорошее и скорее хорошее, среди служащих производственной сферы (инженеров, технологов) - 22,5 \%, домохозяек 19,7 \%, учащихся, студентов - 19,2 \%; плохое и скорее плохое - среди крестьян, работников сельского хозяйства $-47,6 \%$ (рис. 6).

В рамках исследования выявлен уровень среднедушевого дохода в семьях опрошенных в зависимости от их социального положения. При ранжировании уровня дохода целесообразно было сопоставить его с величиной бюджета прожиточного минимума в целом по Республике. На момент проведения опроса (июнь 2018 г.) он составил 206,58 рублей [Бюджет... web].

По указанным среднедушевым доходам на члена семьи в группах с различным социальным положением по данным опроса менее обеспеченными себя считают семьи рабочих, домохозяек, крестьян, работников сельского хозяйства и безработных (более 70 \% опрошенных имеют в среднем доход на члена семьи менее 500 рублей); более обеспеченными - семьи руководителей, предпринимателей, фермеров (табл. 8).

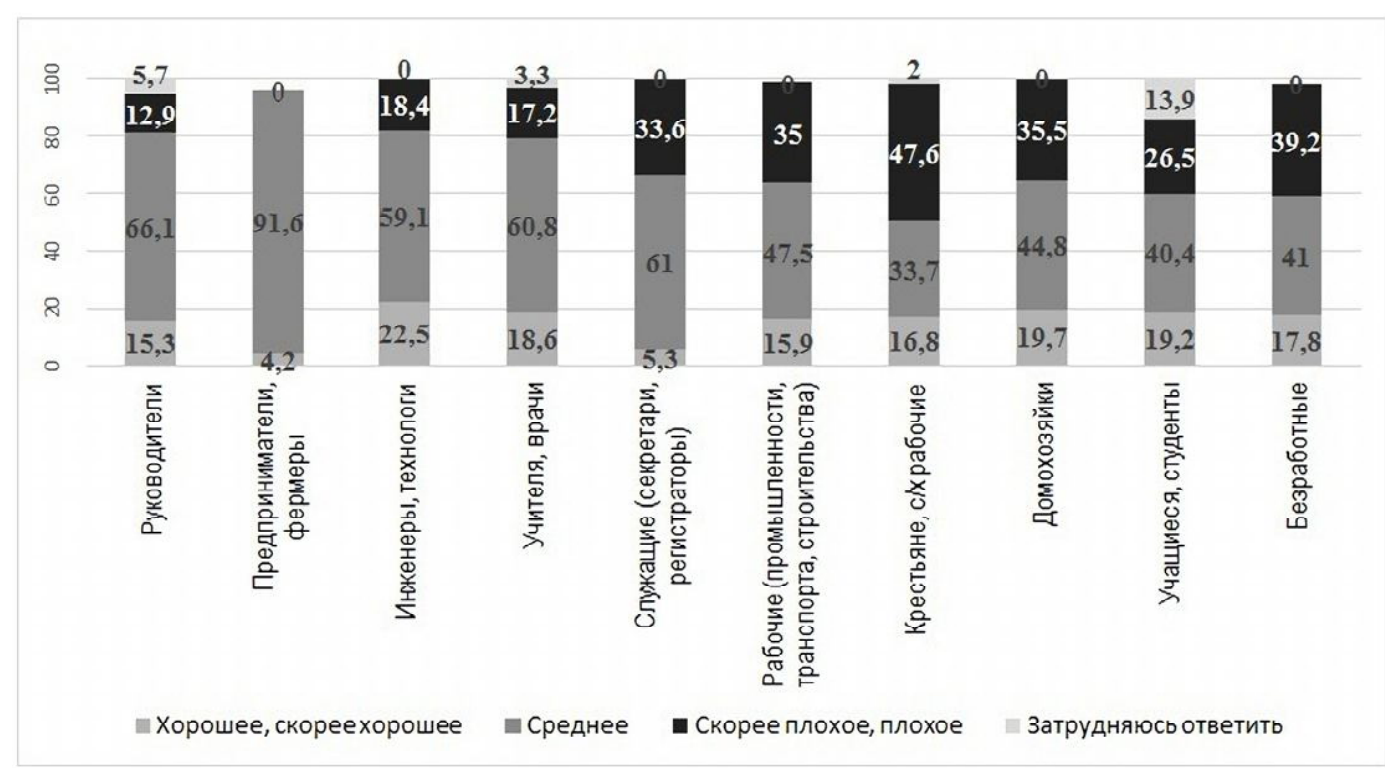

Рис. 6. Оценка сельским населением с различным социальным положением материального положения своей семьи (2018 г.), \%

Таблича 8

Денежный доход сельского населения с различным социальным положением на члена семьи за последний месяц (июнь 2018 г.), \%

\begin{tabular}{|l|c|c|c|c|c|c|c|}
\hline \multicolumn{1}{|c|}{ Социальное положение } & До 500 рублей & $500-750$ & $750-1000$ & $1000-1500$ & $1500-2000$ & $2000-3000$ & От 3000 и выше \\
\hline $\begin{array}{l}\text { Руководители (высшего, сред- } \\
\text { него, низшего звена) }\end{array}$ & 40,4 & 29,0 & 22,4 & 3,0 & - & 2,4 & 2,4 \\
\hline Предприниматели, фермеры & 38,7 & 30,0 & - & 16,0 & - & 5,2 & - \\
\hline $\begin{array}{l}\text { Служащие, спец. производства } \\
\text { (инженеры, технологи) }\end{array}$ & 56,7 & 29,1 & 11,6 & 2,7 & - & - \\
\hline Учителя, врачи & 63,5 & 25,6 & 2,2 & 5,5 & 3,0 & - & - \\
\hline $\begin{array}{l}\text { Служащие (секретари, регистра- } \\
\text { торы и т. п.) }\end{array}$ & 65,5 & 16,7 & 5,7 & 5,5 & 3,4 & - \\
\hline $\begin{array}{l}\text { Рабочие (промышленности, } \\
\text { транспорта, строительства) }\end{array}$ & 77,0 & 14,0 & 7,4 & - & - & - \\
\hline $\begin{array}{l}\text { Крестьяне, работники сельского } \\
\text { хозяйства }\end{array}$ & 72,5 & 13,8 & 6,0 & 2,2 & - & 2,0 \\
\hline Домохозяйки & 73,8 & 11,6 & 14,6 & - & - & - \\
\hline Безработные & 70,4 & 15,7 & - & - & 4,4 & - \\
\hline Учащиеся, студенты & 65,2 & 12,1 & 10,7 & - & - & - \\
\hline
\end{tabular}




\section{БЕЛОРУССКАЯ АКАДЕМИЧЕСКАЯ СОЦИОЛОГИЯ}

На основе анализа данных официальной статистики и результатов эмпирического исследования социально-культурного потенциала сельских регионов можно сделать следующие выводы.

1. Социально-культурный потенциал сельских регионов во многом зависит от специфики социально-культурной инфраструктуры современного села, совокупности социальных, культурных, экономических ресурсов. В отличие от города социально-культурная инфраструктура сельских регионов характеризуется меньшей развитостью и оснащенностью материально-техническими средствами.

2. Показатели деятельности концертных организаций в сельских населенных пунктах и агрогородках косвенно свидетельствуют о финансовой нерентабельности гастрольных мероприятий, количество которых в период за 2010-2016 гг. снизилось больше чем в два раза. Среди базовых элементов культурной инфраструктуры сократилось количество домов культуры и клубных учреждений, в которых сосредоточены любительские коллективы художественного творчества, студии, кружки. Существенно сократилась численность участников клубных объединений по интересам. Вместе с тем ежегодно возрастает количество платных концертов, спектаклей, выставок, что ограничивает возможности малообеспеченных групп сельского населения культурно и организованно проводить свой досуг. Доля посетителей платных мероприятий сократилась в 2,5 раза.

3. Численность библиотечных учреждений сокращается как в городских, так и в сельских регионах. При этом среднее количество пользователей на одну библиотеку увеличилось, что свидетельствует как о востребованности услуг интеллектуально-культурного досуга, так и данных учреждений на селе.

4. В группах с различным социальным положением сельского населения основную долю составляют неработающие пенсионеры. Среди трудоспособного населения наиболее массово представлены рабочие (промышленности, транспорта, строительства) и крестьяне, работники сельского хозяйства.

5. Качеством услуг, предоставляемых кинотеатрами, библиотеками, музеями, театрами, меньше удовлетворены сельские жите- ли, чем городские. При этом сельчане менее притязательны в оценках качества работы учреждений образования, досуга и отдыха, которые имеются по месту жительства. Наиболее высокий уровень удовлетворенности наличием и работой различных объектов культуры выразили жители Гомельской области, наиболее низкий - Витебской. Следует отметить также мнение сельчан Могилевской области $-42,8 \%$ респондентов не удовлетворены работой местных кинотеатров, библиотек, музеев и других объектов культуры.

6. Качество услуг в сфере образования наиболее высоко оценили жители Гродненской и Брестской областей, низкий уровень удовлетворенности зафиксирован среди жителей Витебской области. Старшее поколение (от 50 лет и старше) более позитивно воспринимает качество оказываемых услуг организациями досуга и отдыха, объектами культуры по месту жительства и более критично к современным образовательным услугам. Младшая (до 30 лет) и средняя (30-49 лет) возрастные группы, напротив, выше оценивают качество услуг образования по месту жительства и менее удовлетворены организацией досуга и отдыха, работой кинотеатров, библиотек, музеев. Среди жителей различных регионов больше всего удовлетворены работой культурно-досуговых учреждений жители Гомельской области, меньше всего - Витебской, Могилевской.

7. О наличии финансовых возможностей для посещения концертов, театров, кино, музеев больше всего заявило предпринимателей, фермеров, а также учащихся и студентов. На недостаточность средств больше всего указали служащие без специального образования (секретари, регистраторы и т. п.) и безработные. О невозможности посещения культурно-досуговых мероприятий по причине полного отсутствия средств чаще других заявляют крестьяне, рабочие сельского хозяйства, а также рабочие, учащиеся и студенты.

Среди тех, кто не заинтересован в покупке билетов на культурные мероприятия, больше всего руководителей высшего, среднего, низшего звена, крестьян, работников сельского хозяйства.

8. В самооценке финансовых возможностей оплачивать детские дошкольные учреж- 
дения и платные кружки для своих детей менее оптимистичны служащие производственной сферы (инженеры, технологи) и предприниматели, фермеры. При этом среди инженеров и технологов больше доля тех, кто оценивает материальное положение своей семьи как хорошее и скорее хорошее. Оценивающих свое материальное положение как плохое и скорее плохое больше всего крестьян, работников сельского хозяйства.

9. В зависимости от среднего дохода на члена семьи меньше всего обеспечены семьи крестьян, работников сельского хозяйства, рабочих и безработных; болыше всего обеспечены - семьи руководителей, предпринимателей, фермеров. Большинство групп (кроме крестьян, работников сельского хозяйства) оценивают свое материальное положение как среднее.

10. В успешной реализации социальнокультурного потенциала разных групп сельского населения большую роль играют услуги населению в сфере культуры, которые должны быть доступными независимо от социального положения и места жительства. Необходимо создавать комфортные условия проживания в сельской местности, обеспечивать местным жителям не только материальное, но и духовное благополучие. Игнорирование существующих проблем развития социальнокультурной инфраструктуры и культуры на селе приведет к дальнейшему оттоку молодежи и трудоспособного населения в города.

\section{СПИСОК ЛИТЕРАТУРЫ}

Бюджет... web - Бюджет прожиточного минимума [Финансовый портал Беларуси] // https:// myfin.by/info/byudzhet-prozhitochnogominimuma.

Васильева, Яковлева, Николаева web - Васильева И.А., Яковлева А.В., Николаева А.Н. Финансовый потенциал региона как фактор обеспечения самодостаточного развития территории [Интернет-журнал «Науковедение». 2015. T. 7, № 5] // http://naukovedenie.ru/PDF/ 162EVN515.pdf.

Зайцев, Худяков 2013 - Зайцев В.В., Худяков Д.Н. Инвестиционный потенциал Гомельского региона: оценка и предложения по реализации // Экономика и управление. 2013. № 2 (34). C. $73-85$.
Лемдяева web - Лемдяева Л.А. Ресурсный потенциал региона и подходы к его оценке (на материалах Сахалинской области) [Управление экономическими системами: электронный научный секрет. 2010. № 2 (22)] // https://cyberleninka.ru/ article/n/resursnyy-potentsial-regiona-ipodhody-k-ego-otsenke-na-materialahsahalinskoy-oblasti.

Медведева (ред.) 2017 - Медведева И.В. (ред.). Культура Республики Беларусь: Статистический сборник. Минск: Национальный статистический комитет Республики Беларусь, 2017.

Никулина, Чистникова, Орлова 2012 - Никулина Е.B., Чистникова И.В., Орлова А.В. Экономический потенциал региона и оценка эффективности его использования // Научные ведомости Белгородского государственного университета. Серия: История, Политология. Экономика. Информатика. 2012. Вып. 23/1. № 13 (132). C. $60-65$.

Программа... web - Программа социально-экономического развития Республики Беларусь на 2016-2020 гг.: утв. Указом Президента Республики Беларусь от 15.12.2016 г. № 466 // http://www.government.by/upload/docs/ program_ek2016-2020.pdf.

Сахарова web-Сахарова Л.А. Оценка условий реализации повышения конкурентоспособности экономического кластера на примере регионов Юга России // [Региональная экономика и управление: электронный научный журнал. 2018. № 2 (54)] // https://eee-region.ru/ article/5414/.

Сидорова 2012 - Сидорова Е.И. Экологический потенциал. Кооперация - путь к эффективному использованию ресурсов // Беларуская думка. 2012. № 10. С. 99-103.

Смирнова 2012 - Смирнова Р.А. Сельские регионы как объект социологического исследования // Социологический альманах. 2012. Вып. 3. C. $290-302$.

Соколова, Кобяк (сост.) 2013 - Соколова Г. Н., Кобяк O.B. (cocm). Села социальная структура // Экономико-социологический словарь. Минск: Беларус. навука, 2013.

Терентьева, Баскаков 2014 - Терентьева О.Н., Баскаков С.Н. Финансовый потенциал АПК Саратовской области: ключевые особенности и результативность использования // Финансы и кредит. 2014. № 24 (600). C. $50-56$.

Porter web-Porter M.E. The Economic Performance of Regions [Regional Studies. 2003. Vol. 37.6\&7] // https://pdfs.semanticscholar.org/de0e/ a94b8048b7e7ce4d1ac7193d9bfb9847f735.pdf. 


\section{REFERENCES}

Budget of a subsistence minimum. Financial portal of Belarus. URL: https://myfin.by/info/ byudzhet-prozhitochnogo-minimuma.

Vasilyeva I.A., Yakovleva A.V., Nikolaeva A.N., 2015. Financial capacity of the region as factor of ensuring self-sufficient development of the territory. Online magazine "Naukovedeniye". URL: https:// naukovedenie.ru/PDF/162EVN515.pdf.

Zaytsev V.V., Khudyakov D.N., 2013. Investment potential of the Gomel region: assessment and offers on realization. Economy and management, no. 2 (34), pp. 73-85.

Lemdyaeva L.A., 2010. Resource capacity of the region and approaches to its assessment (on materials of the Sakhalin region). Management of economic systems: electronic scientific secret, no. 2 (22). URL: https://cyberleninka.ru/article/ $\mathrm{n} /$ resursnyy-potentsial-regiona-i-podhody-kego-otsenke-na-materialah-sahalinskoy-oblasti.

Medvedeva I.V. (ed.), 2017. Culture of Republic of Belarus: Statistical collection. Minsk, National statistical committee of Republic of Belarus.

Nikulina E.V., Chistnikova I.V., Orlova A.V., 2012. Economic capacity of the region and assessment of efficiency of its use. Scientific sheets of the Belgorod state university, iss. 23/1, no. 13 (132), pp. $60-65$.
The program of social and economic development of Republic of Belarus for 2016-2020, is approved by the Presidential decree of Republic of Belarus of 15.12.2016 No. 466. URL: https:// www. government.by/upload/docs/ program_ek2016-2020.pdf.

Sakharova L.A.A., 2018. Assessment of conditions of realization of improving competitiveness of an economic cluster on the example of regions of the South of Russia in regions. Regional economy and management: online scientific magazine, no. 2 (54). URL: https://eee-region.ru/ article $/ 5414 /$

Sidorova E.I., 2012. Ecological potential. Cooperation -a way to effective use of resources. The Belarusky thought, no. 10, pp. 99-103.

Smirnova R.A., 2012. Rural regions as object of social research. Sociological almanac, iss. 3, pp. 290-302.

Sokolova G.N., Kobyak O.V. (eds.), 2013. Social structure of a village. The Economical and sociological dictionary. Minsk, Belarusian. navuka.

Terentyeva O.N., Baskakov S.N., 2014. Financial capacity of agrarian and industrial complex of the Saratov region: key features and effectiveness of use. Finance and credit, no. 24 (600), pp. 50-56.

Porter M., 2003. The Economic Performance of Regions. Regional Studies, vol. 37.6\&7. URL: https://pdfs.semanticscholar.org/de0e/ a94b8048b7e7ce4d1ac7193d9bfb9847f735.pdf.

\section{Information about the Author}

Natalia L. Balich, Candidate of Sciences (Sociology), Associate Professor, Head of the Department of Regional Sociology, Institute of Sociology of the National Academy of Sciences of Belarus, Surganova St., 1/2, 220072 Minsk, Republic of Belarus, nlrMinsk@mail.ru, https://orcid.org/0000-0003-1384-7190

\section{Информация об авторе}

Наталья Леонидовна Балич, кандидат социологических наук, доцент, заведующая отделом региональной социологии, Институт социологии НАН Беларуси, ул. Сурганова, 1/2, 220072 г. Минск, Республика Беларусь, nlrMinsk@mail.ru, https://orcid.org/0000-0003-1384-7190 